\title{
CYP3A4 wt Allele
}

National Cancer Institute

\section{Source}

National Cancer Institute. CYP3A4 wt Allele. NCI Thesaurus. Code C52363.

Human CYP3A4 wild-type allele is located in the vicinity of $7 q 21.1$ and is approximately 27 $\mathrm{kb}$ in length. This allele, which encodes cytochrome P450 3A4 protein, plays a role in the oxidation of steroids, drugs, carcinogens and other xenobiotics. CYP3A4 gene dysfunction is associated with both lung cancer and epipodophyllotoxin-induced leukemogenesis. 